УДК 629.113

DOI: https://doi.org/10.26642/ten-2020-2(86)-24-33

\author{
В.П. Сахно, Д.т.н., проф. \\ В.М. Поляков, к.т.н., доц. \\ С.М. Шарай, к.т.н., доц. \\ Д.М. Ященко, к.т.н. \\ Національний транспортний університет
}

\title{
До питання вибору рухомого складу в системі BRT
}

За останнє десятиліття у країнах Америки, Туреччині та в деяких країнах Європи розвивається новий вид пасажирських перевезень у системі Bus Rapid Transport (BRT), яка передбачає рух автобусів по спеціально виділених і часто обгороджених смугах, тобто його повну ізольованість на дорозі від інших видів транспорту. Для підвищення пасажиромісткості у системі BRT використовують триланкові автобуси $і$ тролейбуси. Поряд з незаперечними перевагами трисекційних зчленованих автобусів і тролейбусів, їм притаманні $і$ недоліки - гірма маневреність і стійкість руху порівняно з двосекційними. Крім того, ефективність експлуатаціі таких машин тісно пов'язана з пасажиропотоком, який протягом дня може змінюватися. Аналіз організації перевезень показує, що перспективним може стати автопоїзд, який складається $з$ двох (або трьох) автобусів чи тролейбусів, щзо працюють у зчіпиі, пасажиромісткість яких аналогічна зчленованим автобусам і тролейбусам. У години пік праџює автобусний поӥзд, а у міжпіковий період - кожен автобус окремо (можлива стоянка одного автобуса на відведеному майданчику). Завдяки проведенню теоретичних досліджень доведена доиільність використання у системі BRT триланкового причіпного автопоїзда, щуо складається з трьох однотипних автобусів МАЗ-206 загальною довжиною до 26 м і пасажиромісткістю до 220 пасажирів. Розрахунками доведено, щзо для руху такого автопоӥзда у всьому діапазоні швидкостей достатньо потужності двох двигунів, тобто один з автобусів може використовуватись як пасивний причіп, щуо призведе до поліпшення паливної економічності автобусного поїзда. Теоретично встановлено, щзо за показниками маневреності триланковий причіпний автопоїзд значно перевищує триланковий шарнірно-зчленований автобус.

Ключові слова: триланковий автопоїз; шарнірно-зчленований автобус; система BRT; маневреність.

Актуальність теми. Сучасні системи громадського транспорту все частіше розглядаються як важливий засіб безпечного підвищення мобільності населення, особливо в міських районах, які страждають від зростаючих транспортних заторів. Нова система автобусного руху «Швидкісний автобусний транспорт» BRT, або метробус, є результатом розвитку мережі автобусного суспільного транспорту. Порівняно з метро цей проєкт має суттєві переваги: менша вартість створення мережі, менша вартість рухомого складу, мобільність та ін. Ці переваги проявляються насамперед за максимального використання пасажиромісткості метробусів, тобто під час застосування триланкових метробусів і за умови їх руху з максимально можливими швидкостями.

Триланкові метробус можуть виконуватися за двома основними компонувальними схемами напівпричиню, яка найбільш поширена, і причіпною, яка тільки починає впроваджуватися.

Система BRT передбачає рух автобусів по спеціально виділеним і часто обгородженим смугам, тобто його повну ізольованість на дорозі від інших видів транспорту. У сучасній системі як рухомий склад вибираються зчленовані автобуси (тролейбуси) останнього покоління, оснащені двигунами до 250 кВт. При цьому, як у метро, в салонах метробуса надається перевага місцям для стояння. Завдяки цьому лише один зчленований дволанковий автобус може перевозити до 150 пасажирів [1]. Для підвищення пасажиромісткості в системі BRT можуть використовуватися триланкові автобуси і тролейбуси. Так на найбільшому міжнародному салоні автобусів і комплектуючих Busworld Europe-2019, який проходив у Брюсселі, дебютував незвичайний тролейбус - Trollino 24 (рис. 1). Це трисекційна машина довжиною 24 м, що виготовлена польським виробником Solaris Bus \& Coach. У pух машину приводять два тягові електродвигуни (на 2-й і 3-й осях) потужністю по 160 кВт кожен. Максимальна швидкість руху тролейбуса повною масою 38 т, пасажиромісткістю від 180 до 200 чоловік становить 70 км/год [1]. Трисекційні автобуси випускають низку автомобілебудівних фірм тієї ж пасажиромісткості і з тяговим двигуном потужністю 300 кВт.

Поряд 3 незаперечними перевагами трисекційних зчленованих автобусів і тролейбусів, їм притаманні і недоліки - гірша маневреність і стійкість руху порівняно 3 двосекційними. Крім того, ефективність експлуатації таких машин тісно пов'язана $з$ пасажиропотоком, який протягом дня може змінюватися. Тому перспективним може стати автопоїзд, який складається з двох (або трьох) автобусів чи тролейбусів, 
що працюють у зчіпці, пасажиромісткість яких аналогічна зчленованим автобусам і тролейбусам. У години пік працює автобусний поїзд, а у міжпіковий період - кожен автобус окремо (можлива стоянка одного автобуса на відведеному майданчику).

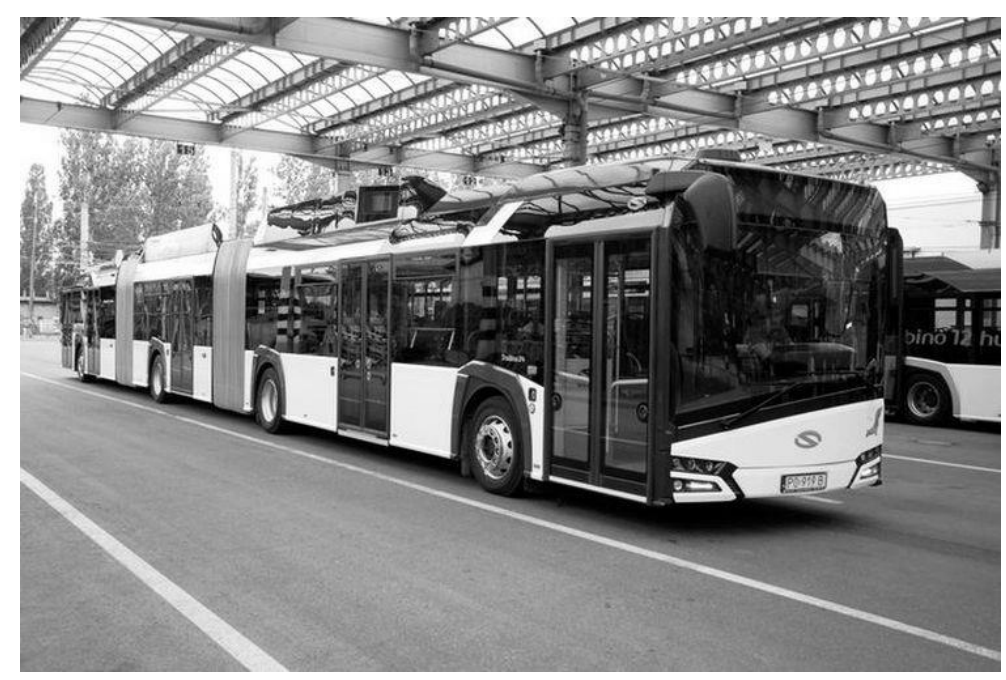

Puc. 1. Тролейбус Trollino 24

Показово, що над ідеєю причіпного автопоїзда, який рухається по дорогах загального користування, працювали і в Києві. Відомий київський фахівець Володимир Пилипович Векліч - автор зчленованих тролейбусів, які вперше були застосовані у колишньому СРСР, а саме у Києві.

Поряд 3 тролейбусним автопоїздом, інститутом «ДержавтотрансНДІпроект» разом 3 Київським автомобільно-дорожнім інститутом у 1973 р. була розроблена конструкція автопоїзда, що складався з двох автобусів ЛАЗ-695, які працювали у зчіпці (рис. 2). Дослідна експлуатація такого автопоїзда на одному 3 маршрутів міста Києва показала його життєздатність. Проте одночасна поява у Києві шарнірнозчленованих автобусів Ikarus-180 зумовила припинення експлуатації зазначеного автопоїзда. Водночас такі причіпні автопоїзди можуть застосовуватися у системі BRT [2].

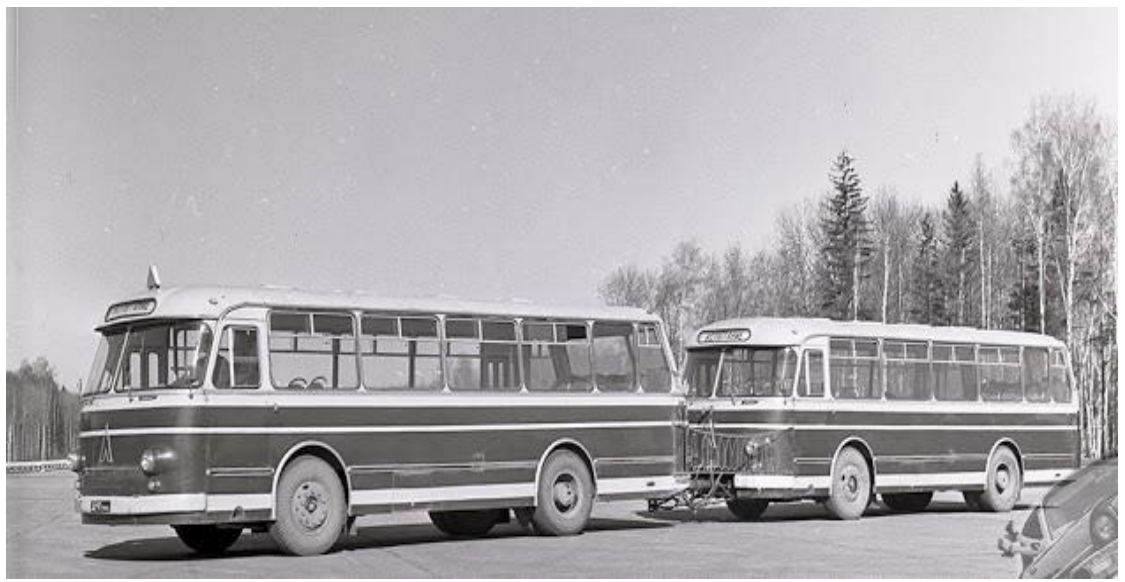

Рис. 2. Автопоїз у складі двох автобусів ЛАЗ-695 у зчіпиі

Попередні дослідження доводять, що метробус (автобусний поїзд) може конкурувати 3 метро у випадку його пасажиромісткості 210-250 чоловік й інтервалу руху 45-60 с. Така пасажиромісткість може бути забезпечена тільки автобусним поїздом у трисекційному варіанті.

Зважаючи на обмеження максимальної довжини автобусного поїзда на рівні 24-25 м, як складові автопоїзда, розглянемо восьмиметрові автобуси МАЗ-206. Пасажиромісткість такого автобуса становить 72 пасажири, потужність тягового двигуна - 160 кВт.

Визначимо необхідну потужність двигунів автобусів трисекційного автобусного поїзда за відомою формулою [3]:

$$
N_{e v}=\frac{f_{v} \times M_{a} \times g \times v_{\max }+k_{B} \times F \times v_{\max }^{3}}{1000 \times \eta_{M}},
$$


де $M_{a}$ - маса метробуса, $f_{v}$ - коефіцієнт опору кочення коліс метробуса, $g$ - прискорення вільного падіння, $v_{\max }$ - максимальна швидкість руху метробуса, $k_{B}$ - коефіцієнт опору повітря, $F$ - площа поперечного перерізу, $\eta_{м}-$ ККД трансмісії метробуса.

На рисунку 3 наведено залежність необхідної потужності силової установки від швидкості руху автобусного поїзда.

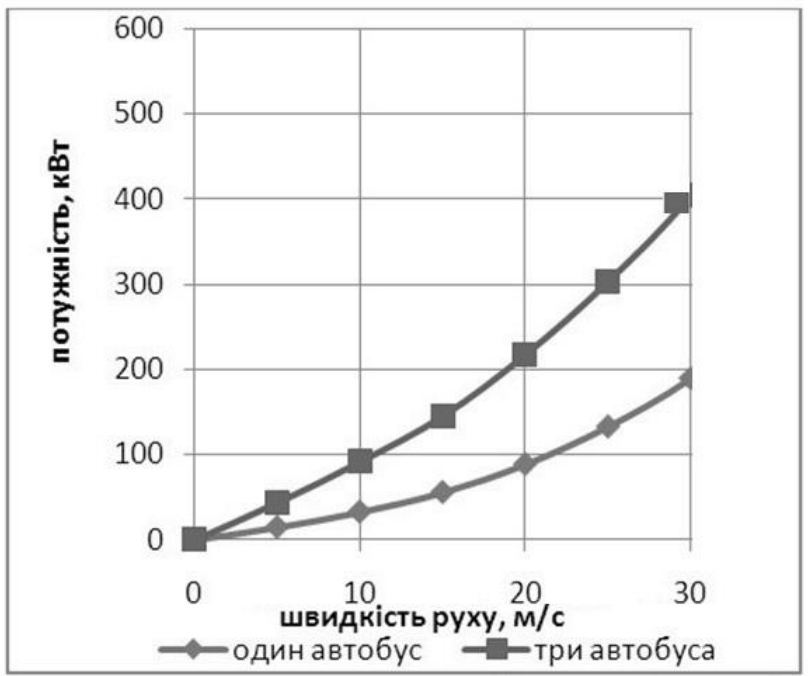

Рис. 3. Залежність необхідної потужності силової установки від швидкості руху автобусного поӥзда

Із наведеної вище залежності бачимо, що для руху автобусного поїзда зі швидкістю 25 м/с необхідна сумарна потужність двигунів має становити 300 кВт, у той час як для одного автобуса вона має бути на рівні 135 кВт. Це свідчить про економічну доцільність використання автобусного поїзда із трьох автобусів, що працюють у зчіпці. Для їх руху у всьому діапазоні швидкостей достатньо потужності двох двигунів, тобто один з автобусів може використовуватись як пасивний причіп, що призведе до поліпшення паливної економічності автобусного поїзда.

Для вирішення питання щодо доцільності використання такого автопоїзда необхідно перевірити його здатність рухатися у міських умовах, де існують обмеження щодо ширини проїздів і перехресть. Ці обмеження визначаються Правилами № 36 СЕК ООН, які регламентують зовнішній і внутрішній габаритні радіуси на рівні 12,5 м і 5,3 м, а також габаритну смугу руху (ГСР) на рівні 7,2 м.

Аналіз останніх публікацій. Перші детальні дослідження експлуатаційних властивостей вантажних триланкових автопоїздів почалися у 80-х роках минулого століття. Найбільш відомі роботи у цьому напрямку Я.Є. Фаробіна [4], М.С. Висоцького [5], В.А. Горєлова [6], В.В. Аюпова [7] та ін.

Для покращення маневреності автопоїздів у конструкції їх причіпних ланок використовують системи керування колесами або осями. У [8] наведено кінематичну модель автопоїзда з керованим за нелінійною стратегією керування причепом, ефективність якої підтверджена експериментально.

Автори [9] пропонують вирішувати проблему відстеження траєкторії руху ланок автопоїзда 3 використанням алгоритму, що прогнозує управління швидкої розподіленої нелінійної моделі, поєднаної 3 нелінійною оцінкою рухомого горизонту для оцінки стану і параметрів руху транспортного засобу. Цей алгоритм управління дозволяє вести систему тягач-причіпна ланка з будь-якої бажаної траєкторії, забезпечуючи високу точність управління.

Проводяться дослідження щодо впливу доріг з різними радіусами заокруглень на стан водія під час управління транспортним засобом і параметри його маневреності [10]. Результати показали, що існують явні відмінності у маневреності транспортних засобів між групами кривих доріг, що впливає на показники безпеки дорожнього руху.

Але варто зазначити, що під час дослідження маневреності рух автопоїздів розглядається як на жорстких, так і на еластичних у бічному напрямі колесах. Загальним у цих роботах можна вважати те, що в системи керування причіпними ланками як задаючого параметра використовувалися кути складання ланок автопоїзда.

Зважаючи на те, що у автопоїзді, який розглядається, кожен автобус має свою індивідуальну систему управління, не пов'язану напрямом з кутом складання, який тим не менше впливає на кінематику повороту автопоїзда, тому дослідження маневреності автобусного поїзда у складі трьох автобусів $є$ актуальними. 
Метою статті $\epsilon$ обгрунтування вибору рухомого складу в системі BRT шляхом визначення показників маневреності автобусного поїзда у складі трьох автобусів МА3-206, що працюють у зчіпці.

Результати дослідження. Проведеними раніше теоретичними i експериментальними дослідженнями [4, 11, 12 та ін.] встановлено, що на попередньому етапі габаритні радіуси повороту і габаритну смугу руху (ГСР) можна визначати на жорстких у бічному напрямку колесах.

Траєкторія кожної ланки автобусного поїзда визначається траєкторією її головної точки [11]. У такому випадку триланковий поїзд можна розділити на дві пари кінематичних ланок - перший і другий автобуси та другий і третій автобуси (рис. 4).

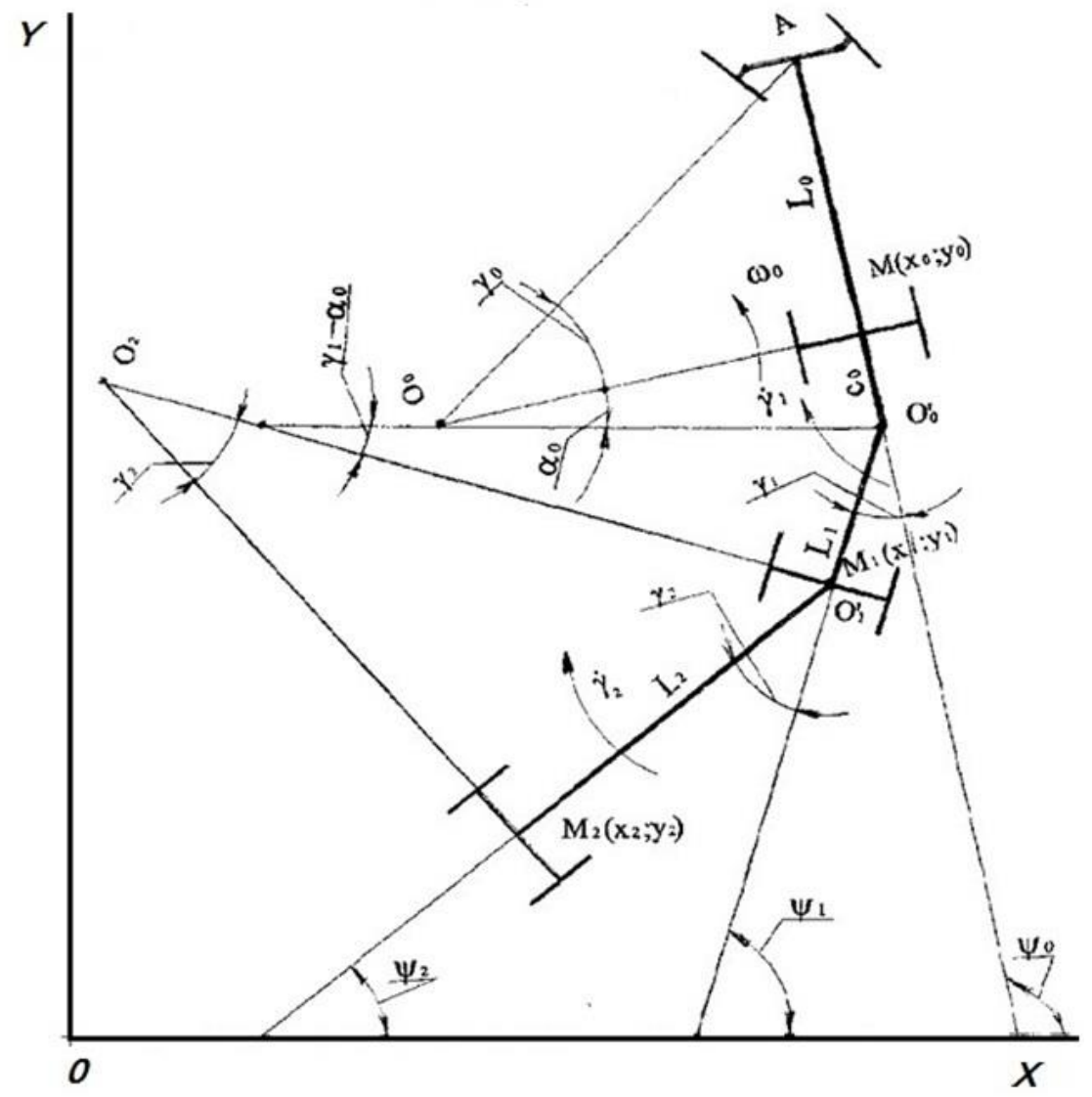

Рис. 4. Схема повороту першої пари кінематичних ланок триланкового автобусного поїда (перший і другий автобуси)

Згідно $з$ теоремою про складання обертання фігури навколо паралельних осей, складний криволінійний рух твердого тіла складається 3 абсолютного руху в нерухомій (абсолютній) системі координат, відносного руху відносно до спряженого з ним ведучого твердого тіла і переносного руху останнього.

Розглянемо ці загальнотеоретичні положення відносно до першої пари ланок автобусного поїзда, а саме перший і другий автобуси. При цьому для спрощення викладок вважаємо, що точка зчіпки автобусів збігається з головною точкою першого автобуса.

Рух ланок автобусного поїзда відносно до опорної поверхні є абсолютним і в кожен даний момент обертання кожна його ланка має свій миттєвий центр обертання: перший автобус т. $\mathrm{O}_{0} \mathrm{i}$ другий автобус - т. $\mathrm{O}_{2}$. Ведена ланка (другий автобус), здійснюючи абсолютний рух навколо центра $\mathrm{O}_{2}$, одночасно переміщується відносно ведучої ланки (першого автобуса) з миттєвим центром О’ ${ }_{0}$ обертання у точці зчіпки. При цьому між поздовжніми осями ланок виникає кут складання $\gamma_{1}$. Рух же першого автобуса $є$ для другого автобуса переносним 3 миттєвим центром обертання в точці $\mathrm{O}_{0}$. Таким чином, ведена ланка другий автобус здійснює складний рух: переносний 3 першим автобусом з кутовою швидкістю $\omega_{c}$, відносний - 3 кутовою швидкістю $\omega_{\kappa}$ і абсолютний - 3 кутовою швидкістю $\omega_{1}$ і з відповідними центрами обертання $\mathrm{O}_{0}, \mathrm{O}_{0}, \mathrm{O}_{2}$. 
Під час одностороннього криволінійного руху автопоїзд проходить декілька стадій [11]:

- стадія початкового прямолінійного руху (перед поворотом), в якій абсолютні миттєві центри швидкостей першого і другого автобуса знаходяться у нескінченності; відносна кутова швидкість ведучої ланки (першого автобуса) дорівнює нулю;

- $\quad$ стадія входження в поворот, у якій рух по головній вхідній траєкторії характеризується тим, що кут повороту керованих коліс першого автобуса збільшується від нуля до деякої заданої водієм величини. Абсолютні миттєві центри обертання першого і другого автобуса поступово переміщуються по лінії $\overline{O_{0} O_{0}^{\prime}} 3$

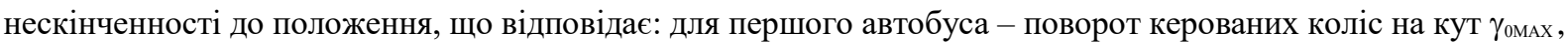
а для другого автобуса - деякому значенню кута повороту його керованих коліс $\gamma_{2} 3$ корекцією від першого кута складання $\gamma_{1}$ ланок. Відстань $\overline{O_{0} O_{0}^{\prime}} \neq 0$, а відносна кутова швидкість обертання причепа $d \gamma_{1} / d t<0$;

- стадія кругового повороту, в якій рух першого автобуса відбувається по коловій траєкторії 3 постійним радіусом. Кут повороту керованих коліс ведучої ланки досягає свого максимального значення на цьому повороті і залишається деякий час постійним. Абсолютний миттєвий центр обертання $\mathrm{O}_{0}$ першого

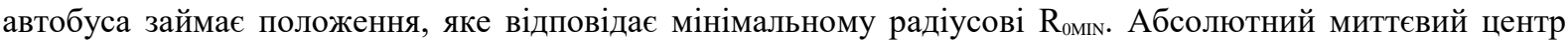
обертання другого автобуса може розташовуватися таким чином. Під час першого варіанта, тобто за умови неграничного повороту, центр $\mathrm{O}_{2}$ не досягає кінця стадії кругового повороту і відстань $\mathrm{O}_{0} \mathrm{O}_{0}^{\prime}$ на цій стадії залишається більше за нуль. Відносна кутова швидкість другого автобуса $d \gamma_{2} / d t<0$. Іншими словами, круговий поворот першого автобуса закінчується до того, як співпадуть переносний і абсолютний центри обертання другого автобуса. Це найбільш поширений випадок повороту автобусного поїзда. За умови другого варіанта, тобто під час граничного повороту, круговий рух автобуса закінчується після того, як переносний i абсолютний центри обертання причепа співпадуть 3 абсолютним центром обертання автобуса. Відносна кутова швидкість $d \gamma_{2} / d t=\omega_{0}=\omega_{1}$, тобто весь автопоїзд обертається як єдине ціле навколо одного центра;

- стадія виходу з повороту, в який рух першого автобуса відбувається по головній вихідній

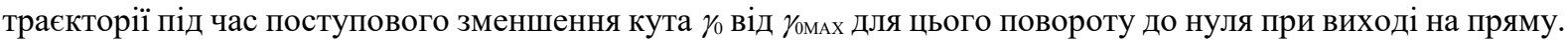
Під час виходу з повороту абсолютні миттєві центри обертання першого і другого автобусів поступово переміщуються у нескінченність, залишаючись на одній лінії $\overline{O_{0} O_{0}^{\prime}}$, а відстань $\overline{O_{0} O_{0}^{\prime}}$ все інтенсивніше збільшується;

- $\quad$ вихід першого автобуса на прямолінійну траєкторію. Ця стадія характерна тим, що, хоча перший автобус і рухається прямолінійно $\left(\gamma_{0}=0, \omega_{0}=0\right)$, другий автобус, як правило, продовжує криволінійний рух, асимптотично наближаючись до прямолінійної траєкторії першого автобуса, і перший кут складання зменшується.

Розглянуті закономірності криволінійного руху першої пари кінематичних ланок триланкового автобусного поїзда, а саме першого і другого автобусів, справедливі і для другої пари кінематичних ланок - другий і третій автобуси.

Аналіз залежностей криволінійного руху автобусного поїзда дає чітку картину процесу повороту. Однак практично важливу задачу визначення положення його причіпних ланок на повороті він не розв'язує. Для цього необхідно знайти величини кутів складання, які визначають положення другого і третього автобусів на повороті.

У [13] отримані рівняння кутів складання для триланкового автопоїзда 3 двома причепами, які можуть бути використані і для триланкового автобусного поїзда з корекцією кутів складання за рахунок кутів повороту керованих коліс другого і третього автобусів. Ці рівняння записані у вигляді:

$$
\begin{aligned}
& \frac{\mathrm{d} \gamma_{1}}{\mathrm{~d} \gamma_{0}}=\frac{\operatorname{tg}\left(\gamma_{0}\right)}{\mathrm{K}_{\Pi} \cdot \mathrm{L}_{0}} \cdot\left(1-\frac{\mathrm{L}_{0}}{\operatorname{tg}\left(\gamma_{0}\right) \cdot \cos \left(\alpha_{0}\right)} \cdot \frac{\sin \left(\gamma_{1}-\alpha_{0}\right)}{\mathrm{L}_{1}}\right) ; \\
& \frac{\mathrm{d} \gamma_{2}}{\mathrm{~d} \gamma_{0}}=\frac{\sin \left(\gamma_{1}-\alpha_{0}\right)}{\mathrm{K}_{\Pi} \cdot \mathrm{L}_{1} \cdot \cos \left(\alpha_{0}\right)} \cdot\left(1-\frac{\mathrm{L}_{1} \cdot \cos \left(\gamma_{1}-\alpha_{0}\right)}{\sin \left(\gamma_{1}-\alpha_{0}\right)} \cdot \frac{\sin \left(\gamma_{2}\right)}{\mathrm{L}_{2}}\right) .
\end{aligned}
$$

Зважаючи на те, що отримані диференціальні рівняння в цілому не інтегруються, їх інтегрування виконано за допомогою прикладного програмного забезпечення для ПЕОМ Mathcad. На рисунку 5 як приклад наведено результати розрахунків кутів складання автобусного поїзда 3 базовими конструктивними параметрами автобуса МАЗ-206, для якого довжина $L_{a}=8,8$ м і база $l=4,27$ м.

Аналіз результатів розрахунків показав:

- поворот усіх елементарних кінематичних ланок здійснюється на першій стадії послідовно, причому друга причіпна ланка забігає більш інтенсивно у внутрішню сторону повороту, збільшуючи другий кут складання порівняно 3 першим. Аналогічно змінюються і швидкості обертання ланок автобусного поїзда незалежно від режиму його повороту. Співвідношення кутів $\gamma_{0}$ i $\gamma_{1}$ в кінці першої стадії повороту становить приблизно 0,45 , у той час як співвідношення кутів $\gamma_{2}$ i $\gamma_{1}-0,87$; 
- кути складання суттєво залежать від режиму криволінійного руху автобусного поїзда. Зі зменшенням режимного коефіцієнта повороту зменшуються і кути складання його ланок $\gamma_{1}$ i $\gamma_{2}$ за одного і того ж значення приведеного кута повороту $\gamma_{0}$ керованих коліс першого автобуса, оскільки автобусний поїзд займає при цьому менш «складене» положення;

- кут складання $\gamma_{2}$ у початковий період повороту автопоїзда може приймати від'ємні значення. Це явище спостерігається тільки під час повороту з відносно великими значеннями режимного коефіцієнта повороту $K_{п}$ і пояснюється тим, що за умови різкого повороту першого автобуса точки зчеплення першого і другого, другого і третього автобуса виходять за лінію початкового прямолінійного руху автобусного поїзда.

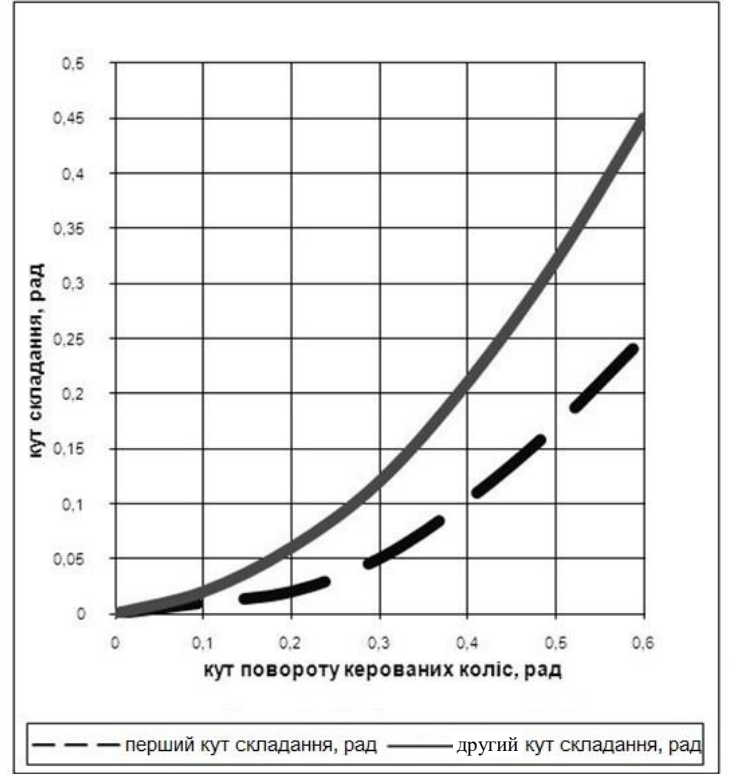

a)

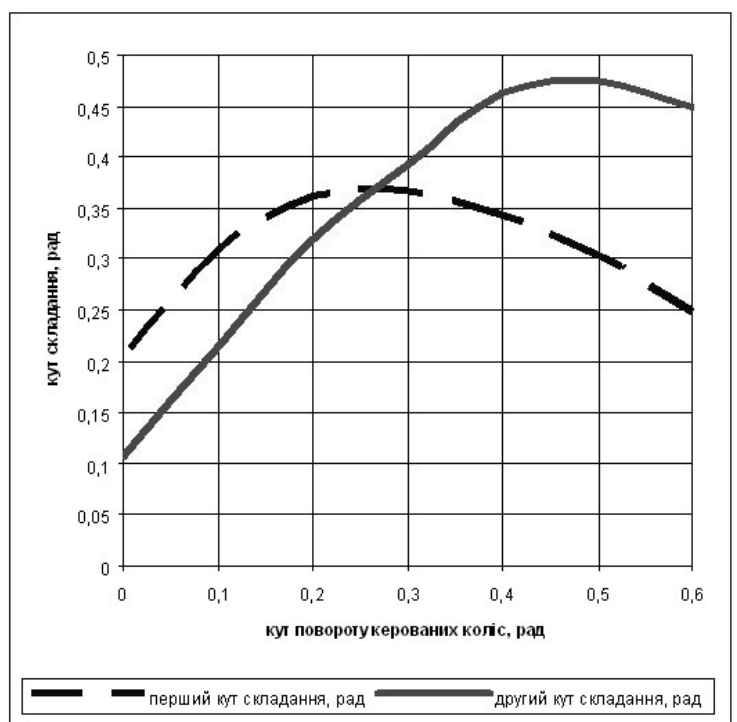

в)

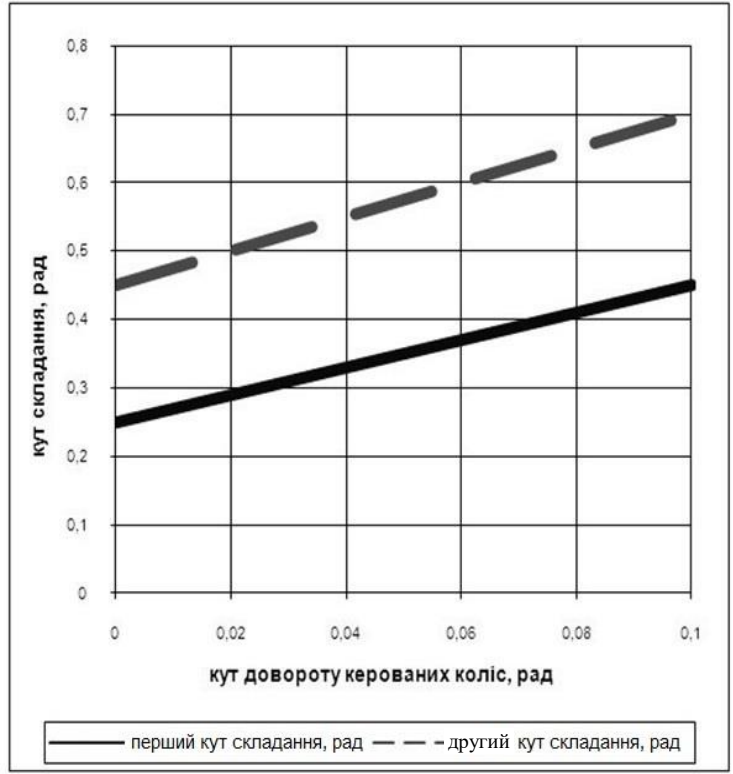

б)

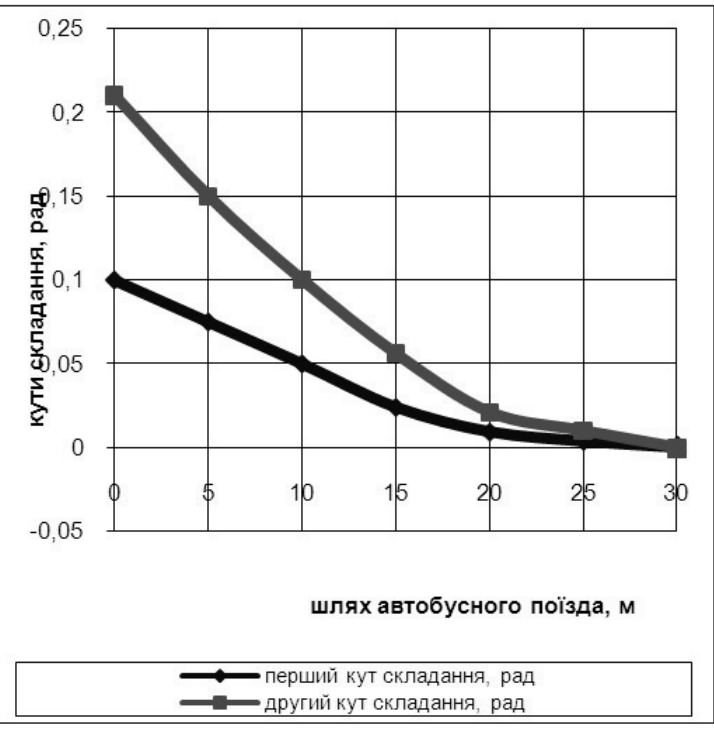

2)

Рис. 5. Зміна кутів складання ланок автопоӥзда для різних стадій повороту: а) вхід в поворот; б) рух по колу; в) вихід із повороту; г) прямолінійний рух першої ланки

За знайденими кутами складання визначимо зміщення траєкторій другого і третього автобусів. Як зазначалося вище, головною точкою першого автобуса $є$ траєкторія руху точки середини ведучого моста. За аналогією до цього вважаємо, що головною точкою другого і третього автобусів є також середина ведучого моста, які позначимо через $\mathrm{M}_{2}$ i $\mathrm{M}_{3}$. 
Оскільки кути складання ланок є функціями від кута повороту керованих коліс усіх автобусів $\left(\gamma_{1}=f\left(\gamma_{0}, \gamma_{\text {к1 }}\right), \gamma_{2}=f\left(\gamma_{0}, \gamma_{1}, \gamma_{\text {к1 }}, \gamma_{\text {к2}}\right)\right)$, то траєкторії руху головних точок другого і третього автобусів необхідно будувати залежно від руху головної точки першого автобуса. Згідно зі схемою (рис. 6) траєкторію руху головних точок усіх автобусів доцільно будувати за двома координатами [14].

Зважаючи на те, що траєкторія головної точки першого автобуса позначена як $x_{0}$ та $y_{0}$, то траєкторії точок другого $\mathrm{M}_{2}$ і третього автобуса $\mathrm{M}_{3}$ будемо позначати $x_{2}, y_{2}$ та $x_{3}, y_{3}$ відповідно.

Тоді (рис. 6) отримаємо такі залежності:

$$
\begin{aligned}
& x_{2}=x_{0}-c_{0} \cdot \cos \left(\delta_{0}\right)-L_{1} \cdot \cos \left(\delta_{0}-\gamma_{1}\right), \\
& y_{2}=y_{0}-c_{0} \cdot \sin \left(\delta_{0}\right)-L_{1} \cdot \sin \left(\delta_{0}-\gamma_{1}\right), \\
& x_{3}=x_{2}-c_{1} \cdot \cos \left(\delta_{0}-\gamma_{1}\right)-\mathrm{L}_{2} \cdot \cos \left(\delta_{0}-\gamma_{1}-\gamma_{2}\right), \\
& y_{3}=y_{2}-c_{1} \cdot \sin \left(\delta_{0}-\gamma_{1}\right)-\mathrm{L}_{2} \cdot \sin \left(\delta_{0}-\gamma_{1}-\gamma_{2}\right),
\end{aligned}
$$

де $\delta_{0}$ - кут нахилу дотичної до траєкторії головної точки першого автобуса; $\gamma_{1}, \gamma_{2}-$ відповідно кути складання між першим і другим та другим і третім автобусами; $c_{0}$ - відстань від головної точки першого автобуса до точки зчіпки з другим автобусом; $c_{1}$ - відстань від головної точки другого автобуса до точки зчіпки з третім автобусом.

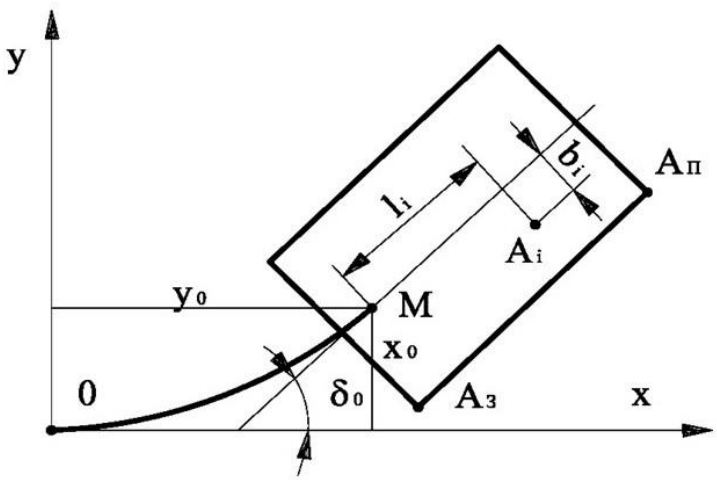

a)

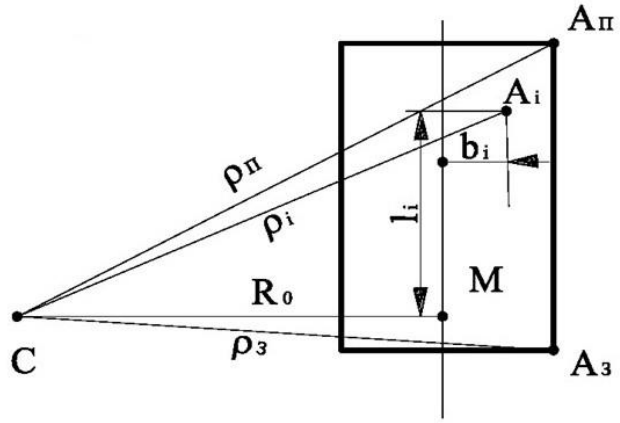

б)

Рис. 6. Схеми до визначення радіусів і координат траєкторії будь-якої точки автомобіля [11].

а) на вході в поворот; б) під час руху по дузі кола; $A_{\Pi} i A_{3}-$ відповідно передня $i$ задня габаритні точки

Розглядаючи перший автобус як плаский прямокутник [14] (рис. 6), можна визначати розташування будь-якої точки в його межах за двома координатами: відстанню від цієї до головної точки $M$ уздовж поздовжньої осі зі знаком «+», якщо точка розташована спереду за напрямком руху, і зі знаком «-» - якщо точка розташована позаду. Ця відстань буде позначатися через $l_{i}$. Другою координатою буде відстань від заданої точки до поздовжньої осі автобуса по перпендикуляру, що опущений з неї на цю вісь.

Розглянемо три можливі випадки руху:

- прямолінійний, коли усі точки автопоїзда рухаються траєкторіями, що паралельні траєкторії головної точки $M$;

- $\quad$ круговий, коли усі точки рухаються по дузі кола з центром в точці $C$ і радіусом головної точки $R_{0}$. Зважаючи на те, що усі точки автопоїзда рухаються по концентричним дугам кіл, простіше за все визначати не координати заданої точки, а її радіус:

$$
\rho_{i}=\sqrt{\left(R_{0}+b_{i}\right)^{2}+l_{i}^{2}}
$$

- по перехідній криволінійній траєкторії. Координати будь-якої точки автопоїзда визначаються як:

$$
\begin{aligned}
& x_{i}=x_{0} \pm l_{i} \cdot \cos \left(\delta_{0}\right) \pm b_{i} \cdot \sin \left(\delta_{0}\right) ; \\
& y_{i}=y_{0} \pm l_{i} \cdot \sin \left(\delta_{0}\right) \pm b_{i} \cdot \cos \left(\delta_{0}\right) .
\end{aligned}
$$

Під час аналізу маневрових властивостей автопоїзда практичне значення мають лише траєкторії його габаритних точок. Так для побудови габаритної смуги руху автопоїзда необхідно лише побудувати траєкторії руху таких двох точок, які рухаються по дугах кіл найбільшого і найменшого радіусів. При цьому варто враховувати, що кожна $з$ ланок автопоїзда обертається навколо власного центра, і тому під час визначення координат внутрішньої і зовнішньої габаритних ліній виникають деякі проблеми. Для спрощення побудови будемо вважати, що найбільш віддаленою точкою кожної з ланок буде передня габаритна точка (розташована ззовні від центра повороту) першого автобуса, а найменш віддаленою - точка умовного перетину задньої осі з внутрішнім (відносно до центра повороту) бортом третього автобуса. Оскільки під час повороту триланкових автопоїздів спостерігається ситуація, коли перший автобус вже 
майже виконав поворот, а третій автобус лише його розпочинає, то більш доцільно визначати зміщення траєкторій головних точок другого і третього автобусів, а потім будувати габаритну смугу руху автопоїзда.

Iз застосуванням розробленої методики з використанням програмного забезпечення Mathcad були визначені кути складання та зміщення траєкторій головних точок другого і третього автобусів. Результати розрахунків наведено на рисунку 7.

За отриманими кутами складання і зміщеннями траєкторій головних точок другого і третього автобусів були побудовані габаритні смуги руху триланкового автопоїзда, що складається з трьох однотипних автобусів МАЗ-206 під час виконання ним різних маневрів (рис. 8).

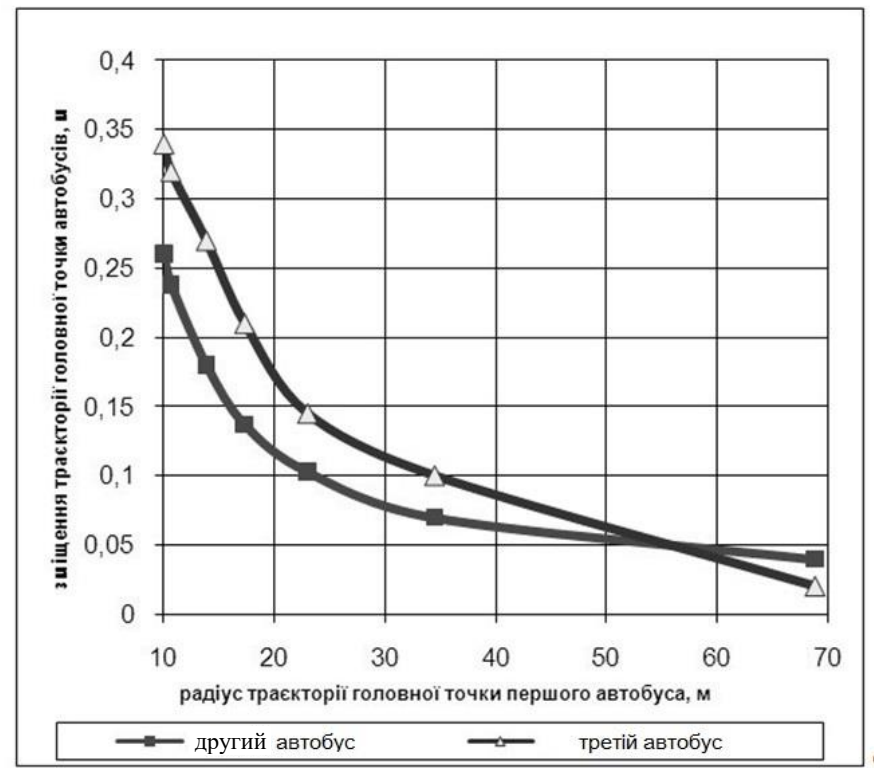

Рис. 7. Зміщення траєкторій головних точок другого і третього автобусів

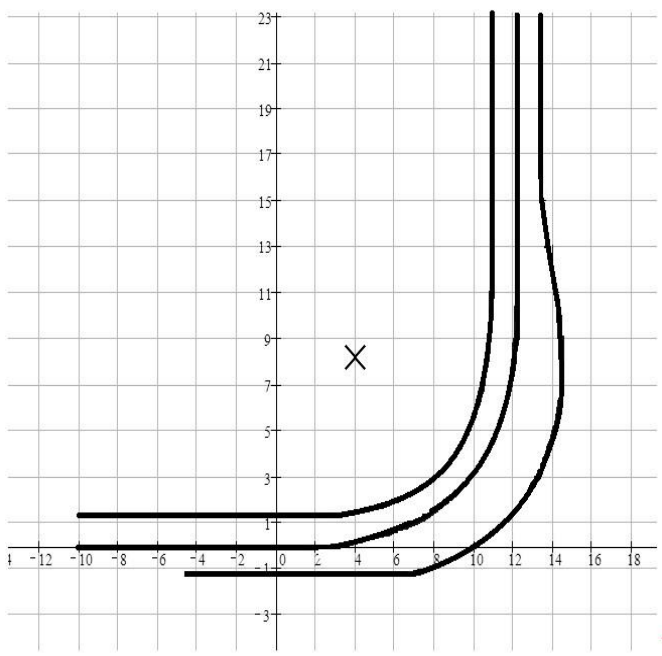

a)

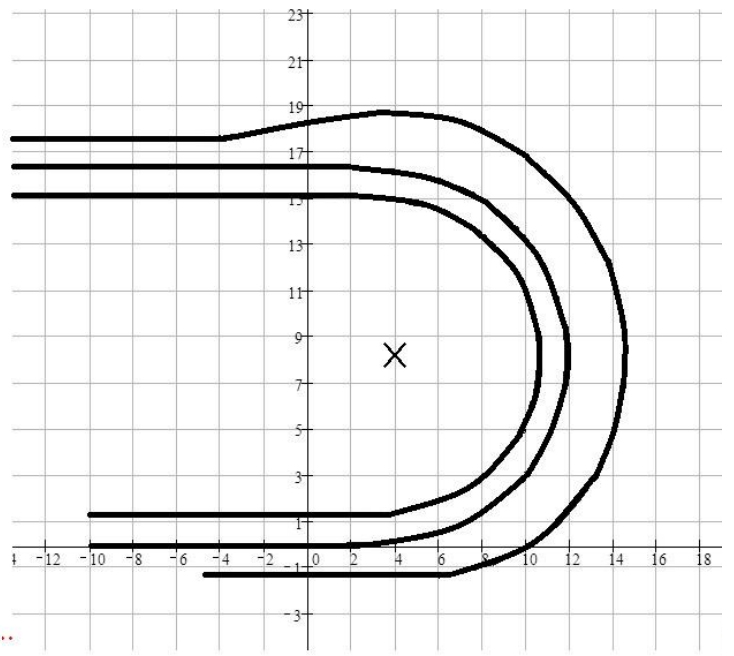

б)

Рис. 8. Траєкторії руху ланок автопоїза за умови повороту на $90^{\circ}$ (а) і $180^{\circ}$ (б)

Як бачимо з графіків, наведених на рисунку 8, габаритна смуга руху автобусного поїзда під час виконання ним найбільш типових маневрів при роботі на міському маршруті не перевищує 3,9 і 4,1 м (при поворотах відповідно на $90^{\circ}$ i $180^{\circ}$ ), що значно менше, чим для триланкового шарнірно-зчленованого автобуса загальною довжиною 24 м (6,8; 8,2 м [13]), тобто за показниками маневреності триланковий причіпний автопоїзд у складі трьох однотипних автобусів загальною довжина кожного 3 них 8 м значно перевищує всі інші автопоїзди.

Висновки та перспективи подальших досліджень. Запропоновано формувати рухомий склад для перевезень у системі BRT з трьох однотипних автобусів МАЗ-206 загальною довжиною до 26 м і 
пасажиромісткістю до 220 пасажирів. Така компонувальна схема дозволяє адаптувати рухомий склад під вимоги змінюваного пасажиропотоку. Результатами теоретичних досліджень доведено, що для руху такого автопоїзда у всьому діапазоні швидкостей достатньо потужності двох двигунів, тобто один 3 автобусів може використовуватись як пасивний причіп, що призведе до поліпшення паливної економічності автобусного поїзда. Також теоретично встановлено, що за показниками маневреності триланковий причіпний автопоїзд значно перевищує триланковий шарнірно-зчленований автобус. Аналіз результатів досліджень дозволяє зробити висновок: використання автопоїзда, який складається 3 трьох однотипних автобусів у системі BRT, дозволяє підвищити безпеку руху та екологічну безпеку рухомого складу автомобільного транспорту.

Подальша робота буде присвячена дослідженню стійкості руху триланкового причіпного автопоїзда, що складається з трьох однотипних автобусів.

\section{Список використаної літератури:}

1. Метробус: скоростной автобус в Стамбуле // Журнал Октобус [Електронний ресурс]. - Режим доступу : https://journal.octobus.io/istanbul_metrobus/.

2. До порівняльної оцінки транспортних засобів для міських перевезень пасажирів в системі BRT / В.П. Сахно, B.М. Поляков, С.М. Місько, О.Є. Омельницький // Автошляховик України. - 2019. - № 6. - С. 7-11.

3. Експлуатаційні властивості автотранспортних засобів. В 3 ч. Ч 1. Динамічність та паливна економічність автотранспортних засобів : навчальний посібник / В.П. Сахно, А.В. Костенко, М.I. Загороднов та ін. Донецьк : Ноулідж, 2014. - 444 c.

4. Трехзвенные автопоезда / Я.Е. Фаробин, А.М. Якобашвили, А.М. Иванов и др. ; под общ. ред. Я.Е. Фаробина.М. : Машиностроение, 1993. - 224 с.

5. Высоикий М.С. Основы проектирования модульных магистральных автопоездов / М.C. Высоикий, С.И. Кочетков, С.В. Харитончик. - Минск : Беларусская наука, 2011. -392 с.

6. Горелов B.A. Математическое моделирование движения многозвенных колесных транспортных комплексов с учетом особенностей конструкции сцепных устройств / В.А. Горелов. - 2012. - № 2 [Электронный ресурс]. Режим доступа : http: http://tecnomag.edu.ru.

7. Аюпов В.В. Исследование маневренных свойств автопоезда на основе системного подхода : монография / B.B. Аюпов. - Пермь : Изд-во ФГБОУ ВПО Пермская ГСХА, 2012. - 96 с.

8. Trailer Steering Control of a Tractor-Trailer Robot / P.Ritzen, E.Roebroek, N.Wouw, Z.-P. van de Jiang and other // IEEE Transactions on Control Systems Technology. - 2016. - Vol. 24, № 4. - P. 1240-1252.

9. Distributed nonlinear model predictive control of an autonomous tractor-trailer system / E.Kayacan, E.Kayacan, H.Ramon, W.Saeys // Mechatronics. - 2014. - Vol. 24, № 8. - P. 926-933.

10. Analysis of Vehicle Maneuverability and Driving Characteristics on a Curved Road Condition / Xuejian Kang and other // KSCE Journal of Civil Engineering. - 2019. - Vol. 23, № 1. - P. 420-432.

11. Закин Я.Х. Маневренность автомобиля и автопоезда / Я.Х. Закин. - М. : Транспорт, 1986. - 137 с.

12. Поляков В.М. Триланкові автопоїзди. Маневреність / В.М. Поляков, В.П. Сахно. - Київ : Національний транспортний університет, 2013. - 200 c.

13. Шляхи поліпшення маневреності метробуса / В.П. Сахно, І.С. Мурований та ін. // Сучасні технології в машинобудуванні та транспорті : науковий журнал. - Луцьк : Луцький НТУ, 2018. - № 2. - С. 122-133.

14. Сахно В.П. До визначення показників маневреності шарнірно-зчленованих автобусів / В.П. Сахно, I.C. Мурований, B.E. Селезньов // Вісник Машинобудування та транспорту : науковий журнал. - Вінниця : Вінницький НТУ, 2016. - № 2. - С. 97-105.

\section{References:}

1. «Metrobus: skorostnoi avtobus v Stambule», Zhurnal Oktobus, [Online], available at: https://journal.octobus.io/istanbul_metrobus/

2. Sahno, V.P., Poljakov, V.M., Mis'ko, Je.M. and Omel'nyc'kyj, O.Je. (2019), «Do porivnjal'noi' ocinky transportnyh zasobiv dlja mis'kyh perevezen' pasazhyriv v systemi BRT», Avtoshljahovyk Ukrai'ny, No. 6, pp. 7-11.

3. Sahno, V.P., Kostenko, A.V., Zagorodnov, M.I. at al. (2014), Ekspluatacijni vlastyvosti avtotransportnyh zasobiv. $V 3$ ch. Ch 1. Dynamichnist' ta palyvna ekonomichnist' avtotransportnyh zasobiv, navchal'nyj posibnyk, Noulidzh, Donec'k, 444 p.

4. Farobin, Ya.E., Yakobashvili, A.M., Ivanov, A.M. et al. (1993), Trekhzvennye avtopoezda, in Farobina, Ya.E. (ed.), Mashinostroenie, Moskva, 224 p.

5. Vysotskii, M.S., Kochetkov, S.I. and Kharitonchik, S.V. (2011), Osnovy proektirovaniya modul'nykh magistral'nykh avtopoezdov, Belarusskaya nauka, Minsk, 392 p.

6. Gorelov, V.A. (2012), «Matematicheskoe modelirovanie dvizheniya mnogozvennykh kolesnykh transportnykh kompleksov s uchetom osobennostei konstruktsii stsepnykh ustroistv», No. 2, [Online], available at: http: http://tecnomag.edu.ru

7. Ayupov, V.V. (2012), Issledovanie manevrennykh svoistv avtopoezda na osnove sistemnogo podkhoda, monografiya, Izd-vo FGBOU VPO Permskaya GSKhA, Perm', 96 p.

8. Ritzen, P., Roebroek, E., Wouw, N., van de Jiang, Z.-P. et al. (2016), «Trailer Steering Control of a Tractor-Trailer Robot», IEEE Transactions on Control Systems Technology, Vol. 24, No. 4, pp. 1240-1252. 
9. Kayacan, E., Kayacan, E., Ramon, H. and Saeys, W. (2014), «Distributed nonlinear model predictive control of an autonomous tractor-trailer system», Mechatronics, Vol. 24, No. 8, pp. 926-933.

10. Xuejian, Kang, Moon, Namgung, Akimasa, Fujiwara, Wonchul, Kim (2019), «Weijie Wang Analysis of Vehicle Maneuverability and Driving Characteristics on a Curved Road Condition», KSCE Journal of Civil Engineering, Vol. 23, No. 1, pp. 420-432.

11. Zakin, Ya.Kh. (1986), Manevrennost' avtomobilya i avtopoezda, Transport, Moskva, $137 \mathrm{p}$.

12. Poljakov, V.M. and Sahno, V.P. (2013), Trylankovi avtopoi'zdy. Manevrenist', Nacional'nyj transportnyj universytet, Kyi'v, $200 \mathrm{p}$

13. Sahno, V.P., Murovanyj, I.S. et al. (2018), «Shljahy polipshennja manevrenosti metrobusa», Suchasni tehnologii' v mashynobuduvanni ta transporti, naukovyj zhurnal, Luc'kyj NTU, Luc'k, No. 2, pp. 122-133.

14. Sahno, V.P., Murovanyj, I.S. and Selezn'ov, V.E. (2016), «Do vyznachennja pokaznykiv manevrenosti sharnirnozchlenovanyh avtobusiv», Visnyk Mashynobuduvannja ta transportu, naukovyj zhurnal, Vinnyc'kyj NTU, Vinnycja, No. 2, pp. 97-105.

Сахно Володимир Прохорович - доктор технічних наук, професор, завідувач кафедри «Автомобілі» Національного транспортного університету.

Наукові інтереси:

- дослідження експлуатаційних властивостей автотранспортних засобів.

https://orcid.org/0000-0002-5144-7131

E-mail: svp_40@ukr.net.

Поляков Віктор Михайлович - кандидат технічних наук, доцент, професор кафедри «Автомобілі» Національного транспортного університету.

Наукові інтереси:

- дослідження експлуатаційних властивостей автотранспортних засобів.

https://orcid.org/0000-0001-7042-3066.

E-mail: poljakov_2006@ukr.net.

Шарай Світлана Михайлівна - кандидат технічних наук, доцент, професор кафедри «Міжнародні перевезення та митний контроль» Національного транспортного університету.

Наукові інтереси:

- транспортна логістика;

- міжнародні перевезення вантажів.

https://orcid.org/0000-0001-6568-4990.

E-mail: svetasharai@gmail.com.

Ященко Дмитро Миколайович - кандидат технічних наук, доцент кафедри «Автомобілі» Національного транспортного університету.

Наукові інтереси:

- дослідження керованості автотранспортних засобів.

https://orcid.org/0000-0003-3674-0089.

E-mail: y_d@ukr.net. 